\title{
ELECTROLYTIC CONDUCTIVITY OF SYNTHETIC ORGANOMINERAL COMPLEXES
}

\author{
Alicja Ksiezopolska \\ Institute of Agrophysics, Polish Academy of Sciences, Dosiwiadczalna 4, P.O. Box 201, 20-290 Lublin 27, Poland \\ e-mail<aksiezo@demeter.ipan.lublin.pl>
}

\begin{abstract}
The mechanism of the formation of organomineral complexes in soils is very complex and still little known. Examination of the complexes in unaltered form, as isolated from the soil, is very difficult due to the dispersing effect of all extraction agents which break the complexes up, destroying their natural properties. It is much easier to perform most of the tests on preparations of organomineral complexes obtained under laboratory conditions. This paper is concerned with model research on the formation of synthetic complexes of humic acids with minerals: Na-montmorillonite, mica, kaolinite at various $\mathrm{pH}$ values (3-7) and in the presence of aluminum ions. The aim of the research was to develop an optimum reaction of suspension for the synthesis of organomineral complexes, to study the role of aluminum ions, and to attempt to determine the degree of their complexity on the basis of the electrolytic conductivity (EC). An important influence of the suspension $\mathrm{pH}$ value on the value of EC was observed. The greatest correlation was found in the organomineral preparations with kaolinite and with aluminum $\left(\mathrm{r}=0.93^{* * *}\right)$. Generally, it can be stated that the degree of reaction of humic acids with minerals depended most of all on the type of mineral, on the $\mathrm{pH}$ value, and on the presence of aluminum.
\end{abstract}

Key words: humic acids, clay minerals, aluminum oxide, degree of complex formation

\section{CONDUTIVIDADE ELÉTRICA DE COMPLEXOS ORGANOMINERAIS SINTÉTICOS}

\begin{abstract}
RESUMO: O mecanismo de formação de complexos organominerais no solo é muito complexo e ainda pouco conhecido. O exame destes complexos em sua forma inalterada, quando isolados do solo, é muito difícil devido ao efeito dispersivo de todos agentes de extração que quebram estes complexos, destruindo suas propriedades naturais. É muito mais fácil executar a maioria dos testes em preparações de complexos organominerais obtidos em condições de laboratório. Este trabalho se preocupa com pesquisa de modelo sobre a formação de complexos sintéticos de ácidos húmicos com minerais: montmorilonita sódica, mica, caulinita em varios pHs (3-7) na presença de ions de alumínio. Seu objetivo foi desenvolver uma reação de suspensão ótima para a síntese de complexos organominerais, para estudar o papel dos ions de Al e procurar determinar o grau de sua complexidade em base de sua condutividade elétrica. Uma importante influência do pH da suspensão foi observada em relação à condutividade elétrica. A maior correlação foi encontrada para preparações organominerais com caulinita e com $\mathrm{Al}\left(\mathrm{r}=0,93^{* * *}\right)$. Em termos gerais, o grau de reação dos ácidos húmicos com os minerais depende, antes de tudo, do tipo de mineral, do pH e da presença de $\mathrm{Al}$. Palavras-chave: ácidos húmicos, minerais de argila, óxido de alumínio, grau de formação do complexo
\end{abstract}

\section{INTRODUCTION}

Humus compounds in soils occur most of all in the form of complexes with the mineral part of the soil. Examination of the complexes in the unaltered forms (after isolation from soil) is very difficult due to the dispersing effect of the extraction agents that disrupt the complexes and thus change their natural properties (Kononowa, 1968). One of the approaches to circumvent this problem is to use organomineral complexes prepared under laboratory conditions. Therefore, attempts were undertaken to synthesize humic acids extracted from a charnozem soil with minerals such as: Na-montmorillonite, mica and kaolinite with the presence of aluminum oxide, and to determine the degree of their reaction on the basis of electrolytic conductivity (EC). The EC turned out to be a good parameter, since the mobility of ions decreased as the complex formation process progressed. The lower the EC of the preparations, the higher the degree of complex formation. EC, i.e. the ability of a solution to conduct electric current as a function of the number of ions in the solution and the electric charge, is believed to be a reliable indicator for the characterization of organic-clay complexes (Cyganski, 1991; Podsiadlo, 1990).

There are many reports in the literature on the concern on the characteristics of such systems as mineralorganic substance-aluminum, iron, and other ion salts (Bruggenwert et al., 1987; Jiang et al., 2002; Goh \& 
Huang, 1984; Keren, 1986; Violante et al., 1999; Yariv \& Cross, 2002). There are, however, few of them concerned with the issue here discussed, i.e. the use of EC as a parameter for the characterization of the degree of reaction of humic acids with minerals (Podsiad³0, 1999; Cygañski, 1991; Ksiezopolska, 1999; 2001). Changes in the reaction of the suspension during the formation of preparations of organomineral complexes are accompanied by a great number of chemical reactions and surface phenomena. The most important of those are transformations of aluminum compounds and compounds containing active hydrogen ions. Aluminum in the form of trivalent ion occurs in the free form at $\mathrm{pH}$ values below 6.05.5 (Davis \& Mott, 1981: Kotowski \& Kotowska, 2000). This ion can be adsorbed on the surface of the soil components as ion-exchangeable aluminum. As $\mathrm{pH}$ grows above 3 , the aluminum ion reacts with hydroxylic ions creating base cations.

In the solid phase system (mineral, humic acid, aluminum oxide - electrolyte solution $0.1 \mathrm{~mol} \mathrm{~L}^{-1} \mathrm{NaOH}$, interesting surface phenomena also occur. They are as follows: adsorption of ions, adsorption of humic acids, hydration of surface, occurrence of inter-particle forces; changes of electrostatic interphase potentials, destruction of the crystal lattice of clay minerals; processes of coagulation or peptization (Davis, 1982; Stawinski et al., 1987; Thomas \& Hargrove, 1984). The great number of physicochemical processes is mainly related to the creation of electrical charges on the surface of the colloids (Dutkiewicz, 1998).

Minerals usually have a constant charge and its magnitude is characteristic of the mineral and of the conditions of its genesis. For most of the soil minerals, the crystal lattice has a negative constant charge, while the surface of the side edges of these constant-charge clay minerals has changeable charge. The magnitude of the constant charge is independent on $\mathrm{pH}$ and the ionic strength of the solution, given that under these conditions there is no decomposition of the crystal lattice of minerals, which likely happens in the case of synthesis of the preparations (Thomas \& Hargrove, 1984). The changeable constant-potential charge is also characteristic of aluminum oxides and hydroxides, silica oxides and amphoteric aluminum, and iron oxides and hydroxyoxides (Bowden et al., 1977).

Changes in the reaction can also cause the destruction of the crystal lattice of clay minerals. Under soil conditions, those processes occur at relatively low $\mathrm{pH}$ (below 4.5), but at a low ionic strength of the soil solution the decomposition of the crystal lattice may happen already at $\mathrm{pH}=7$ (Longan \& Floate, 1985). The above processes occur in the presence of hydrogen ions adsorbed exchangeably on the mineral surface. Depending on the type of mineral, the attack of protons can happen in two ways (Motowicka-Terelak, 1980): on the mineral plate side (kaolinite) or on the face side (montmorillonite), which has a significant impact on the surface phenomena which occur there ( Józefaciuk, 1998; Józefaciuk et al., 1995; Józefaciuk \& Szatanik-Kloc, 2002; Milne et al., 1995).

\section{MATERIAL AND METHODS}

In order to prepare the organomineral preparations, the following minerals were used: Na-montmorillonite-Wyoming- S-Wy-2, mica-montmorillonite-Barasym - SSM-100, Kaolin-Georgia-Kga-1b (from the Department of Geology, University of Missouri, Columbia, USA), humic acid extracted from a charnozem soil using the Schintzer and Stevenson method (Schnitzer \& Schluppli, 1989; Stevenson, 1994) and aluminum oxide $\left(\mathrm{Al}_{2} \mathrm{O}_{3}\right)$ purchased from the Polish Chemical Reagents POCH.

The isolated humic acids were complexed with Na-montmorillonite, mica-montmorillonite or kaolinite. For that purpose, the minerals ( $4 \mathrm{~g}$ ) were suspended in $0.1 \mathrm{~mol} \mathrm{~L}^{-1} \mathrm{NaOH}$ at a ratio of 1:10 (w/v) and amended with humic acids (10\%) and $10 \%$ of $\mathrm{Al}$ (in the form of Al-oxides). The suspensions were adjusted to $\mathrm{pH}$ (3-7), and matured for $24 \mathrm{~h}$ with occasional shaking (Mortland 1970; Ksiezopolska, 1999, 2001). The resulting organomineral complexes were filtrated out, dried in a vacuum oven at $20^{\circ} \mathrm{C}$ over concentrated $\mathrm{H}_{2} \mathrm{SO}_{4}$ and stored at room temperature until analyzed. The analysis included measurements of electrolytic conductivity. EC is related to differences in the mobility of individual ions in the suspension (Kalra \& Maynard, 1991).

In this study, EC was determined using a microcomputer conductivity meter, cc311 (Elmetron, Poland), at $20^{\circ} \mathrm{C}+/-5^{\circ} \mathrm{C}$. The measuring chamber of the conductivity meter was calibrated using standard $\mathrm{KCl}$ solutions of different concentrations. The organomineral complexes were resuspended in deionized water with an electrolytic conductivity of $5.8 * 10-6 \mathrm{~W}-1 \mathrm{~cm}^{-1}$. Prior to the measurement, the suspensions were allowed to stand for $24 \mathrm{~h}$ with occasional mixing (Kalra \& Maynard, 1991).

The results of the EC were statistically calculated, including analysis of variation using the Statgraff software, and analysis of regression using the Excel software. The calculated relations were then described with a linear power, logarithm and exponential equation. The description of the relationship analysis was made using the best fitted function.

\section{RESULTS AND DISCUSSION}

Aluminum compound transformations described above, and numerous physico-chemical phenomena, have a great impact on the electrolytic conductivity of the organomineral complexes under study, related to the 
movement of atoms or groups of atoms. The consequences of current flow through electrolytes are usually to be seen in changes of their condensation and in changes in the chemical factors taking part in their conductivity. The EC turned out to be a good parameter defining the degree of reaction of humic acids with minerals, since the mobility of ions decreased as the complex formation process progresses. The lower EC, the higher the degree of complex formation (Cyganski, 1991; Podsiadlo, 1990).

EC of the organomineral complexes with $\mathrm{Na}-$ montmorillonite ranged from 8.9 to $36.3 \mathrm{mS} \mathrm{cm}^{-1}$ (Figure 1); for the same combinations but with the presence of aluminum - from 8.1 to $15.7 \mathrm{mS} \mathrm{cm}^{-1}$. The lowest value of EC was noted at $\mathrm{pH} 5\left(8.1 \mathrm{mS} \mathrm{cm}^{-1}\right)$ for the combination with aluminum and at $\mathrm{pH} 6\left(8.9 \mathrm{mS} \mathrm{cm}^{-1}\right)$ for the combination without aluminum. The greatest degree of reaction of humic acids with Na-montmorillonite and aluminum occurred at $\mathrm{pH}$ 5. For complexes of humic acids with mica, the EC was in the range from 8.7 to 10.7 $\mathrm{mS} \mathrm{cm}{ }^{-1}$ (Figure 2). For the same combinations but with the presence of aluminum - from 8.8 to $39.4 \mathrm{mS} \mathrm{cm}^{-1}$. The greatest degree of reaction occurred at $\mathrm{pH} 5$ and 6 . For the complexes with kaolinite, EC ranged between 9.6

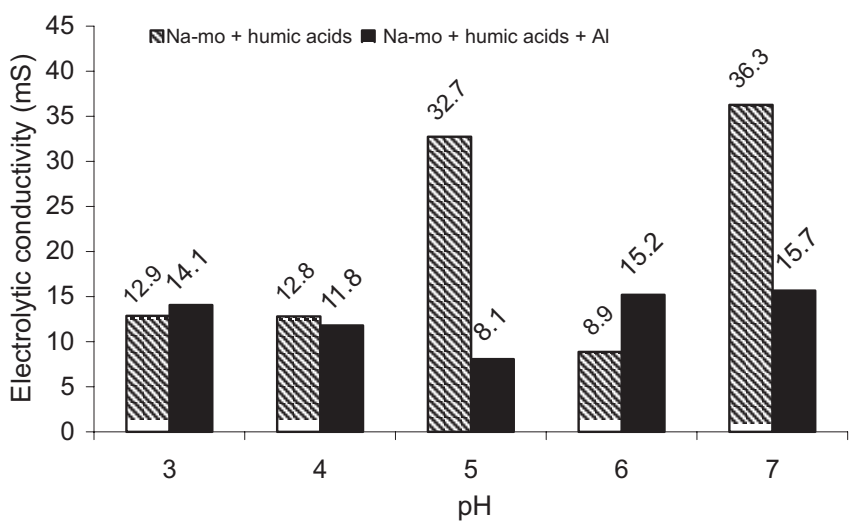

Figure 1 - Correlations between $\mathrm{pH}$ and electrolytic conductivity (EC) for organo-mineral preparations with $\mathrm{Na}$ montmorillonite (+/- Al).

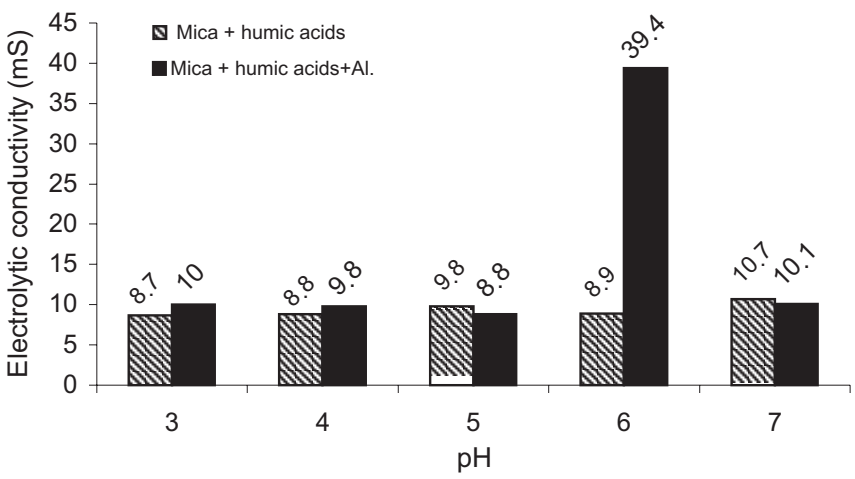

Figure 2 - Correlations between $\mathrm{pH}$ and electrolytic conductivity (EC) for organo-mineral preparations with micamontmorillonite (+/- Al). and $18 \mathrm{mS} \mathrm{cm}^{-1}$ (Figure 3), while for the same combinations with the presence of aluminum - from 9 to $26.7 \mathrm{mS}$ $\mathrm{cm}^{-1}$.

The greatest degree of reaction with kaolinite occurred at $\mathrm{pH}$ 3, 5 and 7. The increase in EC is caused by an increase in the number of ions in the volume unit. The decrease is caused by a decrease in the degree of dissociation of electrolyte and an increase in the co-activity of ions, which causes a decrease in their mobility. Another factor which strongly affects the EC is temperature: as the temperature increases, EC also increases (Podsiadlo, 1990). The degree of reaction of humic acids with minerals depends on the type of mineral and on the $\mathrm{pH}$ of the suspension and on the presence of aluminum. The detailed relations, specification of important differences and a significant growth or decrease of the EC was stated after the statistic analysis of the measurement data obtained.

The results of EC were statistically processed using the Statgraff software for variation analysis and the Excel software for regression analysis. Table 1 shows the results of regression analysis, in which the extension of change of $\mathrm{pH}$ of the suspension of the prepared organomineral preparations was investigated as influenced by the change in EC for all the combinations with minerals in general and individually for the minerals mentioned: Na-montmorillonite, mica and kaolinite enriched with aluminum and without aluminum. Table 1 shows the impact of $\mathrm{pH}$ on the change in EC for the combinations of the mentioned organomineral complexes. The greatest correlations were noted for humic acid complexes with kaolinite with aluminum ( $\left.\mathrm{r}=0.93^{* * *}\right)$ and for humic acid complexes with mica without aluminum $\left(\mathrm{r}=0.75^{* * *}\right)$. The statistical analysis of the results obtained also included variation analysis, for which the Statgraff software was used. Table 2 shows the statistical analysis of the differences between EC of the investigated preparations with aluminum and without aluminum at each $\mathrm{pH}$, separately. An analysis was made on how the addition of aluminum

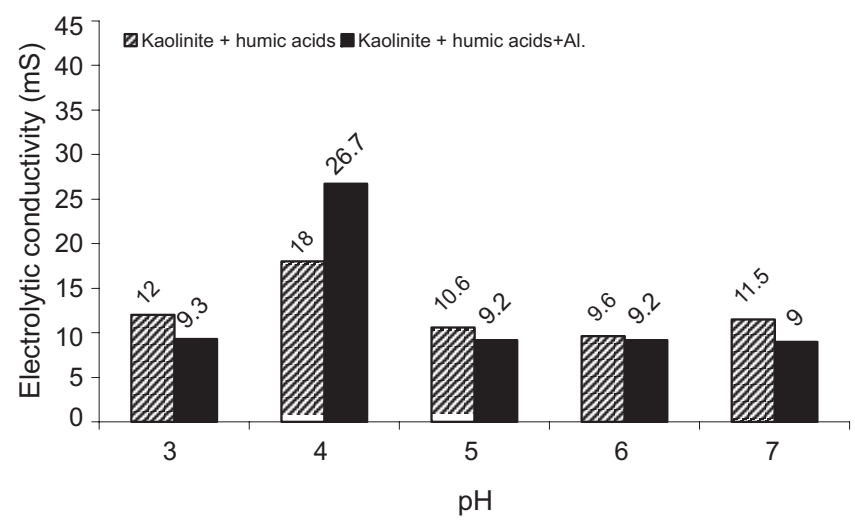

Figure 3 - Correlations between $\mathrm{pH}$ and electrolytic conductivity (EC) for organo-mineral preparations with kaolinite $(+/-\mathrm{Al})$. 
Table 1 - $\mathrm{R}^{2}$ values obtained for relationship between $\mathrm{pH}$ and electrolytic conductivity (EC) for organo-mineral preparation with and without aluminum amendement and influence $\mathrm{pH}$

\begin{tabular}{|c|c|c|c|c|}
\hline Organo mineral preparation $+\mathrm{Al} /-\mathrm{Al}$ (contrast) & Equation & $\mathrm{R}^{2}$ & Significance level & Replicationn \\
\hline Na-montmorillonite $+/-\mathrm{Al}$. & $Y=2.4802 x+4.4458$ & 0.147 & $P<0.05$ & 30 \\
\hline Na-montmorillonite - Al & $Y=4.2883-0.7483$ & 0.283 & $P<0.05$ & 15 \\
\hline $\mathrm{Na}$-montmorillonite $+\mathrm{Al}$. & n.s. & n.s. & & \\
\hline Mica +/- Al & n.s. & & & \\
\hline Mica - Al & $Y=0.431 x+7.2157$ & 0.564 & $P<0.001$ & 15 \\
\hline Mica + Al. & n.s. & n.s. & & \\
\hline Kaolinite +/- Al. & n.s. & n.s. & & \\
\hline Kaolinite - Al. & $Y=0.4127 x+7.2973$ & 0.520 & $P<0.01$ & 15 \\
\hline Kaolinite $+\mathrm{Al}$ & $Y=154.03 x^{-1.216}$ & 0.859 & $P<0.001$ & 15 \\
\hline
\end{tabular}

n.s.: not significant; Na-montmorillonite-Al: Na-montmorillonite without aluminium; Na-montmorillonite+Al: Na-montmorillonite with aluminim; Mica - Al: mica without aluminium; Mica + Al: mica with aluminium; Kaolinite - Al: kaolinite without aluminium; Kaolinite + Al: kaolinite with aluminium.

Table 2 - Differences in electrolytic conductivity (EC) for organo-mineral preparation with and without aluminum amendement (pH 3-7).

\begin{tabular}{|c|c|c|c|c|c|}
\hline Preparation $(+/-\mathrm{Al})$ & $\mathrm{EC}$ & $\mathrm{EC}$ & $\mathrm{EC}$ & $\mathrm{EC}$ & $\mathrm{EC}$ \\
\hline & $\mathrm{pH} 3$ & $\mathrm{pH} 4$ & $\mathrm{pH} 5$ & $\mathrm{pH} 6$ & $\mathrm{pH} 7$ \\
\hline $\mathrm{Na}-\mathrm{m} .+\mathrm{HA} / \mathrm{Na}-\mathrm{m} .+\mathrm{HA}+\mathrm{Al}$. & + & - & - & + & - \\
\hline Mi. + HA/Mi. + HA + Al. & + & + & - & + & 0 \\
\hline $\mathrm{Ka} .+\mathrm{HA} / \mathrm{Ka} .+\mathrm{HA}+\mathrm{Al}$. & - & + & - & 0 & - \\
\hline
\end{tabular}

HA: Humic acids; Na-m.: Na-montmorillonite; Mi.: Mica; Ka.: Kaolinite; EC: Electrolytic conductivity; (+): statisticlly significant increase; (-): statisticlly significant drop; (0): no significant difference.

influenced the change in the parameters at $\mathrm{pH} 3-7$. The changes of EC under the influence of aluminum addition, at each $\mathrm{pH}$ separately, and in the case of complexes with Na-montmorillonite presented an increase in EC at pH 3 and 6. A decrease occurred at $\mathrm{pH} 4.5$ and 7. In the case of complexes with mica, an increase occurred at $\mathrm{pH} 3,4$ and 6. A decrease occurred at $\mathrm{pH} 5$. At $\mathrm{pH} 7$, no differences in EC were observed.

In the case of complexes with kaolinite, an increase in the value of the analyzed parameter occurred at $\mathrm{pH} 4$; at $\mathrm{pH} 3,5,7$ there was a decrease in EC. At $\mathrm{pH}$ 6 no difference was noted.

\section{CONCLUSIONS}

EC proved to be a trustful parameter to characterize the degree of complex formation of organomineral preparations, since the mobility of ions decreased with increasing degree of complex formation.

The lower the electric conductivity the higher the degree of complex formation. Most of the preparations under study showed a low EC, which indicates a good level of reaction.

The degree of reaction of humic acids with minerals depends on the type of mineral, $\mathrm{pH}$ of the suspension, and on the presence of aluminum.
Addition of aluminum induces a significant increase of the degree of reaction of humic acids with minerals.

A positive correlation of EC with $\mathrm{pH}$ of the organomineral complexes was found. The highest correlation was observed in the case of the organomineral complexes with kaolinite with aluminum $\left(\mathrm{r}=0.93^{* * *}\right)$, and for complexes with mica without aluminum $\left(r=0.75^{* * *}\right)$.

\section{REFERENCES}

BOWDEN, J.W.; POSNER, A.M.; QURIK, J.P.Ionic adsorption on variable charge mineral surfaces, theoretical charge development and titration curves. Australian Journal of Soil Research, v.15, p.121-136, 1977.

BRUGGENWERT, M.G.M.; KEIZER, P.; KOOREVAAR, P. Adsorption of aluminum ions by montmorillonite: influence on aluminium speciation. Netherlands Journal of Agricultural Science, v.35, p.259-269, 1987.

CYGAÑSKI, A. Electrical-analytical methods. Warsaw: Wydawnictwo Naukowo-Techniczne, 1991.

DAVIS, J.A. Adsorption of natural dissolved organic matter at the oxide/ water interface. Geochimica et Cosmochimica Acta, v.46, p.2381-2393, 1982.

DAVIS, H.; MOTT, C.J.B. Titrations of fulvic acid fractions I: Interactions influencing the dissociation-reprotonationequilibria. Journal of Soil Science, v.32, p.379-391, 1981.

DUTKIEWICZ, E. Physicochemical surfaces. Warsaw: Wydawnictwo Naukowo-Techniczne. 1998. 224p.

GOH, T.B.; HUANG, P.M. Formation of hydroxy Al.-montmoryllonite complexes as influenced by citric acid. Canadian Journal of Soil Science, v. 64, p.411-421, 1984. 
JIANG, J.Q.; COOPER, C.; SABEHA, OUKI. Comparison of modified montmorillonite adsorbents. Chemosphere, v.47, p.711-716, 2002.

JÓZEFACIUK, G. Changes of surface properties of soils and clay minerals in acidification and alkalization processes. Acta Agrophysica, v.15, p.115, 1998.

JÓZEFACIUK, G.; SZATANIK-KLOC, A. Soil acidity and its effect on plants. Acta Agrophysica, v.59, p.90, 2002.

JÓZEFACIUK, G.; HAJNOS, M.; SOKO£OWSKA, Z.; REGNER, M. Influence of surface coverage by humic acids on surface free energy and wettability of quartz and kaolin. Polish Journal of Soil Science, v.28, p.30-35, 1995.

KALRA, Y.P.; MAYNARD, D.G. Methods manual for forest soil and plant analysis. Outario, 1991. p.35-37. (Information Report, X-319).

KEREN, R. Reduction of the cation-exchange capacity of montmorillonite by take-up of hydroxy Al polymers. Clays and Clay Minerals, v.22, p.41-47, 1986.

KONONOWA, M.M. Organic matter in soils, its structure, properties, and methods of study. Warsaw: PWRL, 1968.

KOTOWSKI, M.; KOTOWSKA, U. Mobilization and transport of aluminum, zinc, copper and lead in acidified podzolic soils. Acta Agrophysica, v.31, p.78, 2000.

KSIEZOPOLSKA, A. Specific surface area as a parameter characterizing degree of reaction of humic acids with bentonite and illite. Acta Agrophysica, v.23, p.59-64, 1999.

KSIEZOPOLSKA, A. Assessment of the conditions for the formation of organic-mineral complexes in soils on the basis of surface properties. International Agrophysics, v.15, p.165-172, 2001.

LONGAN, K.A.B.; FLOATE, M.J.S. Acidity in upland and hill soils: cation exchange capacity, $\mathrm{pH}$ and lime requirement. Journal of the Science of Food and Agriculture, v.36, p. 1084-1092, 1985.
MILNE, C.J.; KINNBURGH, D.G.; de WIT, J.C.M.; van RIEMSDIJK, W.H.; KOOPAL, L.K. Analysis of proton binding by a peat humic acid using a simple electrostatic model. Geochemica et Cosmochimica Acta, v.59, p.1101-1112, 1995.

MORTLAND, M.M. Clay-organic complexes and interactions. Advances in Agronomy, v.22, p.75-117, 1970.

MOTOWICKA-TERELAK, T. Response of some crops to the presence of active aluminum fractions in the soil in a pot experiment. Pamietnik Pulawski, v.73, p.151-165, 1980.

PODSIADLO, H. Laboratory practice book of physical chemistry. Wroclaw: Oskar Lange Academy of Economics, 1990.

SCHNITZER, M.; SCHLUPPLI, P.Method for the Sequential extraction of organic matter for soils and soil fractions. Soil Science Society of America Journal , v.53,p.1418-1424, 1989.

STEVENSON, F.J. Humus chemistry: genesis, composition, reactions. New York: John Wiley \& Sons, 1994.

STAWIÑSKI, J.; JÓZEFACIUK, G.; WIERZCHOE, J. Methodological aspects of soil acidity measurements. Zeszyty Problemowe Postepów Nauk Rolniczych, v.344, p.127-135, 1987.

THOMAS, G.W.; HARGROVE, W.L. The chemistry of soil acidity. In: ADAMS, F. (ED) Soil acidity and liming. 2.ed. Madison: ASA, 1984

VIOLANTE, A.; ARIENZO, M.; SANNINIO, F.; COLOMBO, C.; PICCOLO, A.; GRIANFREDA, L. Formation and characterization of $\mathrm{OH}$-Al-humate-montmorillonite complexes. Organic Geochemistry, v.30, p.461-468, 1999.

YARIV, S.; CROSS, H. Organo clay complexes and interactions. New York: Marcel Dekker, 2002. 688p.

Received July 02, 2004

Accepted February 11, 2005 